\title{
Collaboration, workshops, and symposia
}

OPEN

Stefan M. Pulst, MD,

Dr med

Correspondence to

Dr. Pulst:

stefan.pulst@hsc.utah.edu

\section{Neurol Genet}

2017;3:e157; doi: 10.1212/

NXG.0000000000000157
Readers may have noticed the presence of a March issue of Neurology ${ }^{\circledR}$ Genetics that added to the customary bimonthly publication schedule. The March issue is a supplement focused on research presented by the International Stroke Genetics Consortium (ISGC).

Genetics of stroke is paradigmatic for the challenges of analyzing polygenic risk in highly complex disease phenotypes with significant environmental and lifestyle confounders. The consortium brings together stroke neurologists and geneticists that collaborate to achieve sample sizes and diverse cohorts to define genetic risk for a number of stroke subtypes.

The supplementary issue published proceedings of the 19th and 20th ISGC workshops. ${ }^{1-3}$ The ISGC workshops have been held on a semiannual basis since the first meeting in 2007. The Department of Neurology at the University of Utah sponsored a workshop in 2014, and I could personally witness that members of ISGC are highly interactive and committed to sharing of data. In addition to the excitement for discovery, the group also shared in a desire to sample the local surroundings, including regional cuisine, hiking, and skiing.

Neurology: Genetics recently published the proceedings from another group of geneticists. ${ }^{4}$ This research conference dealt with the phenotypic diversity associated with mutations in the ATP1A3 gene. The ATP1A3-related disease conference presented a summary of findings, whereas the ISGC proceedings will allow the reader to access individual abstracts.

It is the hope of the editors that these types of collaborations of the journal with genetics consortia will be mutually beneficial and provide platforms for the rapid dissemination of new research findings.

\section{STUDY FUNDING}

No targeted funding reported.

\section{DISCLOSURE}

S.M. Pulst serves on the editorial boards of Journal of Cerebellum, NeuroMolecular Medicine, CONTINUUM, Experimental Neurology, Neurogenetics, and Nature Clinical Practice Neurology; receives research support from NIH, Target ALS, National Ataxia Foundation, and ISIS Pharmaceuticals; has consulted for Ataxion Therapeutics; served on a speakers' bureau for Athena Diagnostics, Inc.; is a stockholder of Progenitor Life Sciences; has received license fee payments from Cedars-Sinai Medical Center; holds patents for Nucleic acids encoding ataxin-2 binding proteins, Nucleic acid encoding Schwannomin-binding proteins, Transgenic mouse expressing a polynucleotide encoding a human ataxin-2 polypeptide, Methods of detecting spinocerebellar ataxia-2 nucleic acids, Nucleic acid encoding spinocerebellar ataxia-2 and products related thereto, Schwannomin-binding proteins, and Compositions and methods for spinocerebellar ataxia; and receives an honorarium from the AAN as the Editor of Neurology: Genetics. Go to Neurology.org/ng for full disclosure forms.

\section{REFERENCES}

1. Anderson CD, Boncoraglio G, Falcone G. Proceedings of the 19th and 20th International Stroke Genetics Consortium Workshops. Neurol Genet 2017;3:S1. doi: 10.1212/ NXG.0000000000000137.

2. Debette S, Saba Y, Vojinovic D, et al. 19th Workshop of the International Stroke Genetics Consortium, April 28-29, 2016, Boston, Massachusetts, USA. Neurol Genet 2017;3: S2-S11. doi: 10.1212/NXG.0000000000000100.

3. Woo D, Debette S, Anderson C. 20th Workshop of the International Stroke Genetics Consortium, November 3-4, 2016, Milan, Italy. Neurol Genet 2017;3:S12-S18. doi: 10. 1212/NXG.0000000000000136.

4. Rosewich H, Sweney MT, DeBrosse S, et al. Research conference summary from the 2014 International Task Force on ATP1A3-Related Disorders. Neurol Genet 2017;3:e139. doi: 10.1212/NXG.0000000000000139. 


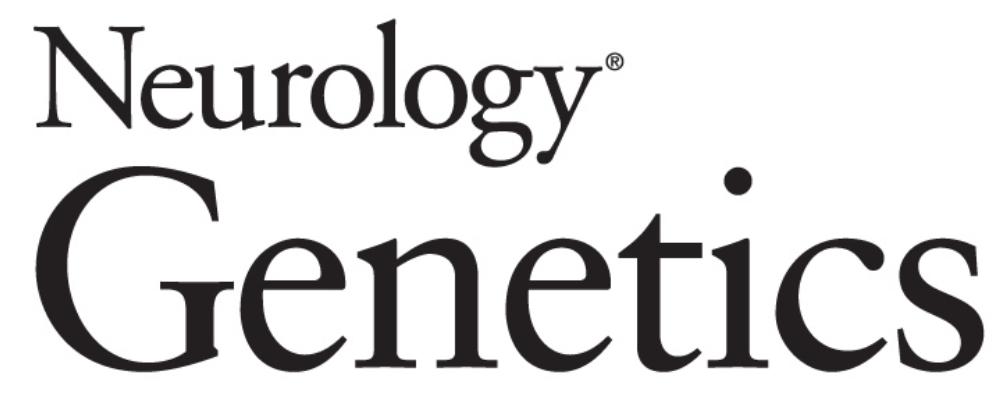
Collaboration, workshops, and symposia Stefan M. Pulst
Neurol Genet 2017;3;
DOI 10.1212/NXG.0000000000000157

This information is current as of June 15, 2017

\section{Updated Information \&} Services

References

Permissions \& Licensing

Reprints including high resolution figures, can be found at: http://ng.neurology.org/content/3/3/e157.full.html

This article cites 4 articles, 4 of which you can access for free at: http://ng.neurology.org/content/3/3/e157.full.html\#\#ref-list-1

Information about reproducing this article in parts (figures,tables) or in its entirety can be found online at:

http://ng.neurology.org/misc/about.xhtml\#permissions

Information about ordering reprints can be found online: http://ng.neurology.org/misc/addir.xhtml\#reprintsus

Neurol Genet is an official journal of the American Academy of Neurology. Published since April 2015, it is an open-access, online-only, continuous publication journal. Copyright Copyright $\odot 2017$ The Author(s). Published by Wolters Kluwer Health, Inc. on behalf of the American Academy of Neurology.. All rights reserved. Online ISSN: 2376-7839.

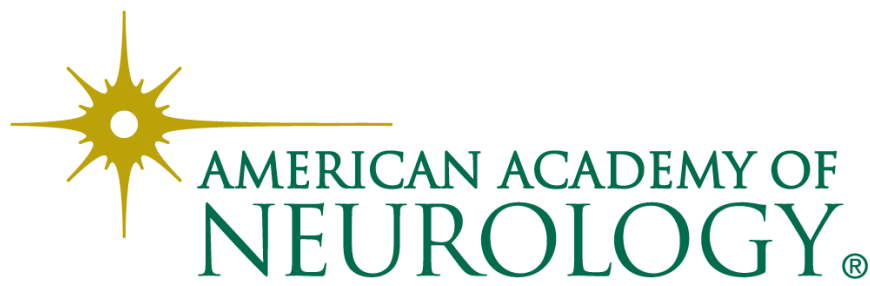

